\title{
Determinants of emerging technologies adoption in the South African financial sector
}

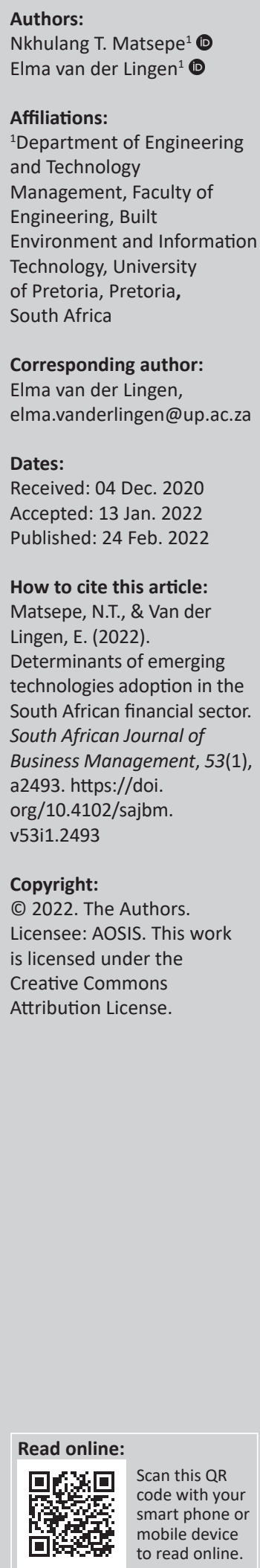

Purpose: The fourth industrial revolution (4IR) enables firms to leverage various emerging technologies to reduce operating costs, improve business efficiencies and gain competitive advantage. This article uncovers the determinants influencing emerging technology adoption, particularly artificial intelligence (AI), cloud computing and distributed ledger technologies (DLT), in South African (SA) financial services firms.

Design/methodology/approach: Seventeen technology experts from the SA banking, insurance, financial technology and financial regulation and compliance sectors were interviewed. A semi-structured interview was used to conduct one-on-one interviews, followed by a focus group interview. Qualitative data were analysed using a thematic network analysis.

Findings/results: The results revealed that the determinants - adopter traits, technology usability, industry characteristics, organisational leadership and organisational characteristics - were influential towards technology adoption. It is suggested that the new model could be strengthened further by incorporating a new construct, leadership diversity, which had not been previously proposed in the literature.

Practical implications: By understanding the influential adoption determinants, leaders can take bold, calculated risks in adopting AI, cloud computing and DLT. However, the importance, prior to adopting these technologies, of clearly understanding the need for them, and their business benefits is also emphasised.

Originality/value: Research on the adoption of AI, cloud computing and DLT in the SA financial sector is limited. This article leverages the models of the diffusion of innovations (DOI), the technology-organisation-environment (TOE) and the technology readiness index (TRI) to propose a new model that illustrates technology adoption in the SA financial sector at individual and firm levels.

Keywords: technology adoption; 4IR; fourth industrial revolution; emerging technologies; financial sector.

\section{Introduction}

The fourth industrial revolution (4IR) is rapidly transforming business processes and models across a range of sectors. Emerging innovative technologies - such as artificial intelligence (AI), machine learning (ML), distributed ledger technologies (DLT) and cloud computing present various opportunities for organisations that manage to adopt these capabilities successfully. Studies have explored the implications of the 4IR for organisations of varying sizes and across various industries (Barreto, Amaral, \& Pereira, 2017; Centre of Excellence in Financial Services, 2017; Haddud, Desouza, Khare, \& Lee, 2017; Kunwar, 2019). For financial services organisations, investment in AI and cloud computing will improve their ability to implement emerging technologies most relevant to solving their critical business problems (Propson \& Galaski, 2020).

Emerging technologies such as blockchain present secure mechanisms for creating, transferring and storing data (OECD, 2018). The analysis of large complex data sets, commonly referred to as 'big data', enables financial services organisations to model consumer-risk profiles accurately, thus providing financial products that are tailored to address the consumer's needs (Hassani, Unger, \& Beneki, 2020). Through interconnected 'smart technological devices', the internet of things (IOT) enables financial organisations to generate big data (OECD, 2018). The successful adoption of emerging technologies, therefore, may serve as a source of competitive advantage in the modern economic environment. 
Existing research exploring adoption determinants of emerging technologies, particularly AI, ML, DLT and cloud computing, in the context of the South African (SA) financial sector is limited. This article contributes towards addressing this gap and provides financial services organisations with greater insights into the factors that influence the decision to adopt and use emerging technologies. A novel contribution is made through the development of a new technologyadoption model that seeks to model individuals' adoption behaviour in their personal and work environments. The article also explores the adoption challenges encountered by financial services organisations during the adoption of these technologies, enabling technology leaders in the sector to revise and improve adoption strategies.

\section{Literature review}

\section{Financial technology}

The literature presents a compelling argument for the adoption of digital technologies in the financial sector. According to Alt, Beck and Smits (2018), technology-driven financial solutions can digitally transform entire value chains and positively impact banking clients, channels (bank branches and online platforms) and traditional financial services providers (FSPs), for example, insurers, banks, nonbanks and interbank system networks. Financial technology (fintech) combines innovative business models with technology solutions to facilitate the provision of daily financial services (Md Husin, Haron, \& Aziz, 2020, p. 13). For FSPs such as insurers, fintech solutions present opportunities to innovate across processes including client advisory management and risk management. For example, big data enable insurers to offer personalised risk premiums to their clients (Puschmann, 2017). Studies further suggest that various factors influence fintech adoption across different global locations (Arner, Barberis, \& Buckley, 2016).

For organisations and consumers in the West, fintech adoption appears to be largely driven by the results of the 2008 financial crisis; whereas, in Africa, adopters are in pursuit of economic opportunities (Arner et al., 2016). A study by Saksonova and Kuzmina-Merlino (2017) noted that fintech adoption in Latvia was very low compared with the European financial sector. This was attributed to a lack of public awareness regarding innovative financial products and services. Strict regulatory requirements in the Latvian financial sector also inhibited the development of fintech start-up firms.

In addition to the 2008 financial crisis contributing towards the emergence of fintech, Alt and Puschmann (2012) indicate that this global disaster along with the continuously evolving behaviour of banking customers, the emergence of nonbanking FSPs and the rate at which innovative information technology (IT) solutions are diffusing into downstream financial processes is driving the sector towards a more customer-oriented landscape. A customer-oriented financial services infrastructure increases the bargaining power of technology end-users by introducing new interfaces to which they can access financial services, thereby generating opportunities for fintech start-up firms to penetrate the sector (Alt \& Puschmann, 2012). The adoption of fintech solutions in the sector has also generated concerns regarding the extent to which financial regulators supervise these technologies.

Zalan and Toufaily (2017) discovered that technology executives in the Middle East and North Africa (MENA) region believed that fintech start-ups were not as regulated as incumbent banking institutions, and were, thus, more favourably positioned to disrupt the banking sector. However, in a contrasting statement, Zalan and Toufaily (2017) indicated that stringent regulatory requirements for financial advice prevented fintech start-ups from offering lower fees to consumers in the region. Fintech is an emerging concept and has not yet been formally supervised by financial regulators in the region. This also contributes to the varying opinions about the extent of fintech regulation in the MENA region. The rapid development of fintech products coupled with the significant rate at which non-regulated fintech providers have entered the financial market, has presented significant challenges for financial regulators around the world (Gerlach, Simmons, \& Lam, 2016).

The consequences of inadequate regulatory oversight are illustrated by the bankruptcy of Ezubao, a peer-to-peer (P2P) lending platform in China which was suspected to have defrauded over 900000 victims (Albrecht, Morales, Baldwin, \& Scott, 2017; Wang, 2018). This platform facilitated financial lending to individuals who had been denied loans by banks because they were deemed to be 'high risk' (Saksonova \& Kuzmina-Merlino, 2017). As the adoption of emerging technologies in the SA financial sector increases, regulators will need to play a more critical role in protecting customers against incurring financial losses.

The South African Reserve Bank (SARB) has acknowledged this risk and has emphasised the implications of inadequate regulatory oversight as fintech adoption in SA increases (SARB, 2017). The SARB will have to indicate clear guidelines on how both fintech firms and incumbent banks will need to comply with existing regulatory requirements. Failure to achieve this may result in systemic implications that will put the stability of the banking sector at risk (Coetzee, 2018).

By partnering with fintech firms early during the development phase, regulators will be able to steer fintech development towards acceptable regulatory frameworks and promote sound financial innovation (Saksonova \& Kuzmina-Merlino, 2017). However, adopting a 'wait-and-see' approach may also enable regulators to focus only on fintech innovations. These appear to be significantly adopted by the market (Arner et al., 2016), allowing regulators to determine whether the market adopts fintech innovations before amending regulatory policies.

\section{Technology adoption models}

Studies have summarised the most popular individual and firm-level technology-adoption models in information 
systems research (Taherdoost, 2018; Van den Berg \& Van der Lingen, 2019). The complex social networks in financial services organisations warrant an examination of adoption behaviour at both individual and firm levels. This article leverages constructs from the diffusion of innovations (DOI), technology-organisation-environment (TOE) and technology readiness index (TRI) models to examine technology adoption.

\section{Diffusion of innovations}

The DOI model has its roots in sociology, and has four main elements: time, the innovation, channels of communication and the social system (Rogers \& Shoemaker, 1983). The model considers the transfer of innovations within social systems via appropriate channels of communication over time to predict users' adoption patterns (Rogers \& Shoemaker, 1983; Taherdoost, 2018).

In addition to the main elements of innovation diffusion, the DOI model has three main characteristics: innovation characteristics, adopter characteristics and the innovationdecision process (Taherdoost, 2018). The innovation characteristics are trialability, relative advantage and complexity (Rogers \& Shoemaker, 1983). Adopters are characterised as early adopters, innovators, laggards, early majority and late majority (Rogers \& Shoemaker, 1983; Taherdoost, 2018). The innovation-decision process outlines five phases of an information-seeking process in which the potential adopters are encouraged to reduce their perceived uncertainty about a technological innovation and thus increase adoption (Miranda, Farias, Schwartz, Pascualote, \& De Almeida, 2016).

\section{Technology-organisation-environment framework}

The TOE framework was developed as a way to unveil the dimensions of an organisation's context that affect the rate at which innovations are adopted (Aboelmaged, 2014). The framework consists of three contextual dimensions: technological, organisational and environmental (Aboelmaged, 2014; Al-jabri \& Alabdulhadi, 2016). The technological context describes adopters' perceptions of the technology's attributes, for example, perceived benefits and ease of use; the organisational context examines the organisational characteristics such as firm size and management structure; and the environmental context describes the firm's interaction with other firms, regulatory bodies and consumers (Amini \& Bakri, 2015; Awa, Ojiabo, \& Orokor, 2017; Tornatzky \& Fleischer in Lin, 2014). Unlike the DOI model, the TOE framework focuses solely on firmlevel technology adoption whilst also incorporating environmental aspects (Amini \& Bakri, 2015).

Scholars (Aboelmaged, 2014; Lin, 2014; Lin \& Lin, 2008) have examined the TOE framework to validate its theoretical depth and effectiveness in examining readiness for various innovations. Aboelmaged (2014) found that the TOE determinants - such as anticipated benefits and firm size, amongst others - influenced elements of e-maintenance technology readiness. Competitive pressure was found to influence electronic business (e-business) diffusion (Lin \& Lin, 2008), whilst the readiness of e-maintenance in manufacturing firms was not influenced by this determinant (Aboelmaged, 2014).

\section{Technology readiness index}

'Technology readiness' describes an individual's propensity to embrace new technology to accomplish goals in his or her work lives or homes (Parasuraman \& Colby (2001) in Lai, 2017). The TRI model measures the extent to which an individual is ready to accept and use new technologies, and has four dimensions: optimism, innovativeness, discomfort and insecurity (Nugroho \& Fajar, 2017; Nugroho, Susilo, Fajar, \& Rahmawati, 2018). High levels of optimism and innovativeness promote technology adoption, whilst an individual's level of discomfort and insecurity inhibit adoption (Aboelmaged, 2014; Awa et al., 2017). The technology readiness level categorises individuals into laggards, paranoids, sceptics, pioneers or explorers.

Regarding 4IR technologies in the financial sector, laggards may prefer banking via traditional physical banking channels (such as visiting the bank branches) over modern digital banking platforms. These users are generally the last group to adopt emerging technology (Nugroho et al., 2018). Innovations excite paranoids; however, their perception of technology is also driven by some elements of fear, and so these users will consider risk factors such as the regulatory implications of P2P lending before completely adopting the technology. Sceptics have a low motivation to accept innovations. These users must, therefore, be exposed to the potential benefits of incurring lower banking fees before they can accept 4IR technologies. Pioneers show significant optimism about innovations; however, these users will also stop using the technology if they encounter any significant challenges (Nugroho et al., 2018). Lastly, explorers are typically the first group of users to try out new technology, and will eagerly commit to sharing data about their driving patterns with insurance firms to try out innovative 'pay-as-you-drive' capabilities (Tselentis, Yannis, \& Vlahogianni, 2016).

\section{Conceptual model}

The limited research on influential determinants of AI, cloud computing and DLT in the SA financial sector allows for a deeper understanding of this phenomenon from the individual's perspective. This article proposes a conceptual model towards addressing this gap. The model is formulated with relevant constructs drawn from the DOI, TOE and TRI models. Studies (Aboelmaged, 2014; Miranda et al., 2016; Rogers \& Shoemaker, 1983; Taherdoost, 2018) show that these models have been widely referenced to model technology adoption at individual and firm levels.

Table 1 outlines the proposed determinants and constructs of the conceptual model illustrated in Figure 1. The conceptual model is discussed in Table 1 to propose the influences exerted by the model's constructs. 
Figure 1 illustrates the proposed influences exerted by the determinants and constructs outlined in Table 1.

The conceptual model in Figure 1 illustrates the proposed individual level determinants: adopter traits and technology usability, as well as the firm level determinants: industry characteristics, organisational leadership and organisational characteristics. The development of this model along with the proposed influences exerted by the model's constructs on adoption use behaviour is discussed in the following section.

\section{Effects of adopter traits on innovation adoption}

'Adopter traits' describe an individual's innate ability to acquire new technical skills, as well as his or her inclination to try innovations that optimise his or her current methods of working. Adopter traits can be characterised by constructs such as knowledge of innovation, technical skill and personal innovativeness (Awa et al., 2017; Nugroho et al., 2018; Rogers

\begin{tabular}{|c|c|c|}
\hline Number & Determinant & Model constructs \\
\hline 1 & Adopter traits & $\begin{array}{l}\text { - Knowledge of innovation (DOI) } \\
\text { - } \quad \text { Technical skill (TOE) } \\
\text { - Personal innovativeness (TRI) }\end{array}$ \\
\hline 2 & Technology usability & $\begin{array}{l}\text { - } \quad \text { Trialability (DOI) } \\
\text { - } \quad \text { User insecurity (DOI) } \\
\text { - URI) }\end{array}$ \\
\hline 3 & Industry characteristics & $\begin{array}{l}\text { - Competitive pressure (TOE) } \\
\text { - } \text { Regulatory support (TOE) } \\
\text { - Customer demands (TOE) }\end{array}$ \\
\hline 4 & Organisational leadership & $\begin{array}{l}\text { - Opinion leadership (DOI) } \\
\text { - Risk orientation (DOI) }\end{array}$ \\
\hline 5 & Organisational characteristics & $\begin{array}{l}\text { - } \quad \text { Firm size (TOE) } \\
\text { - } \quad \text { Top management support (TOE) } \\
\text { Communication mechanisms (TOE) }\end{array}$ \\
\hline
\end{tabular}

DOI, diffusion of innovations; TRI, Technology readiness index; TOE, Technology-organisationenvironment.
\& Shoemaker, 1983). It is proposed that adopter traits (proposition - P1 in the conceptual model) will influence AI, cloud computing and DLT adoption.

Aboelmaged (2014) and Nugroho and Fajar (2017) state that adopter traits such as personal innovativeness and user optimism promote innovation adoption, whilst insecurity and discomfort impede innovation adoption. Saksonova and Kuzmina-Merlino (2017) attributed the low penetration of fintech innovations in Latvia to a lack of knowledge about the innovations. Jaafar, Ramayah, AbdulAziz and Saad (2007) and Aboelmaged (2014) noted that employees who were highly rated in technical skills had a higher likelihood of being effective in technology readiness and support. It is proposed that knowledge of the innovation, technical skill and personal innovativeness (Propositions P1-1, P1-2, and P1-3 in the conceptual model) will positively influence AI, cloud computing and DLT adoption.

\section{Effects of technology usability on innovation adoption}

'Technology usability' refers to the extent to which an organisation believes that a technology can be learned and effectively integrated (Van den Berg \& Van der Lingen, 2019). Awa et al. (2017) found technology usability to be a critical factor in the adoption of innovative technologies in Nigerian service-based SMEs. This was attributed to the inhibition of adoption caused by complex, sophisticated information systems. It is proposed that technology usability (Proposition P2) will influence AI, cloud computing and DLT adoption.

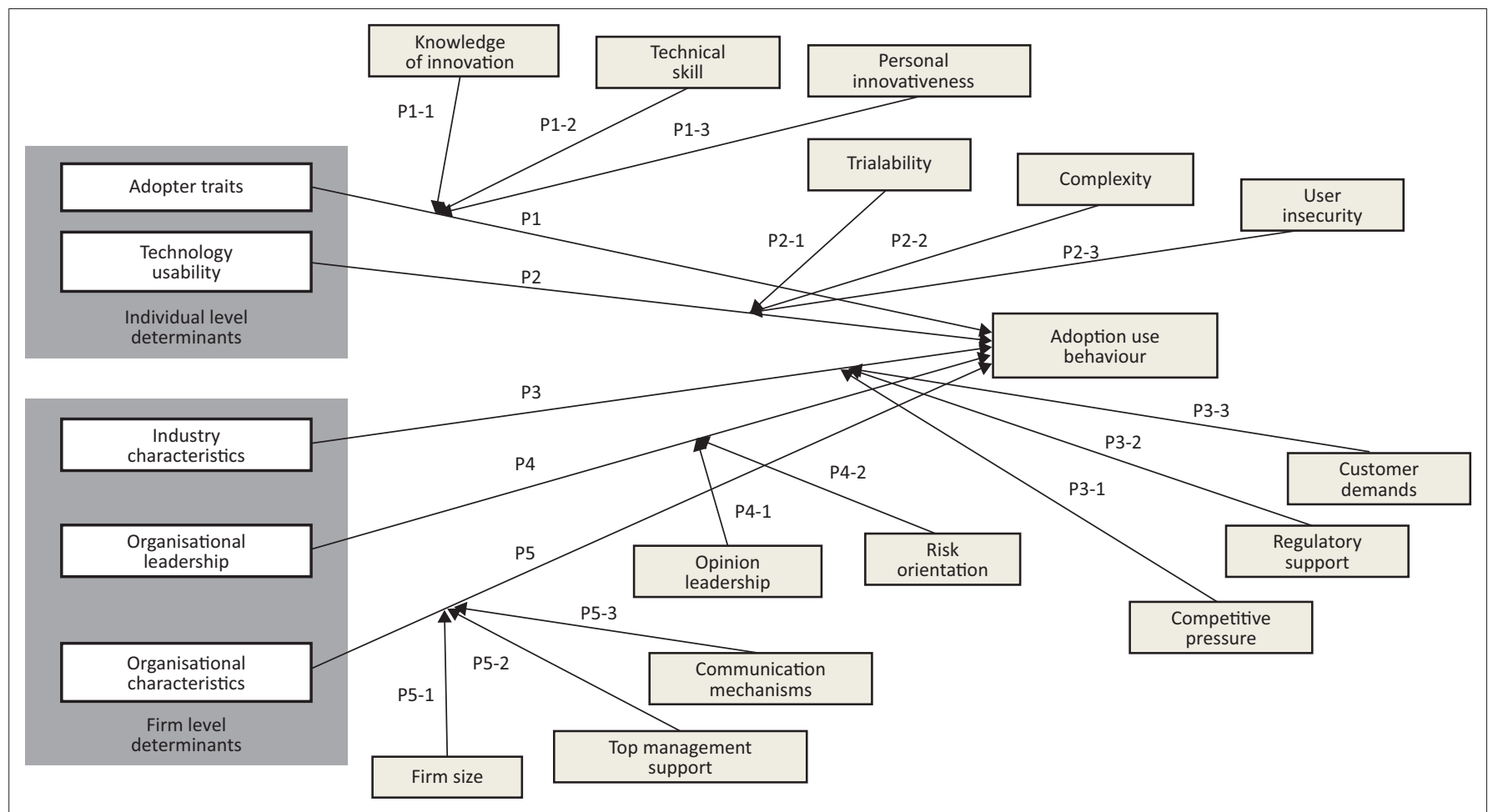

FIGURE 1: Conceptual model for the adoption of fourth industrial revolution technology in the South African financial sector. 
Cheung, Chang and Lai (2000), and Al-Jabri and Sohail (2012) described 'complexity' as the extent to which an innovation could be considered relatively difficult to comprehend, and found that it inhibited the adoption of internet-based technologies. Au and Kauffman (2008), Mallat (2007) and Ondrus and Pigneur (2006) and Al-jabri and Sohail (2012) found that the perceived complexity of mobile banking technology negatively influenced users' intentions to adopt the technology. It is proposed that complexity (Proposition P2-1) will negatively influence AI, cloud computing and DLT adoption.

'Trialability' describes the ability of a user to experiment with an innovation before adopting it (Al-jabri \& Sohail, 2012). As potential adopters experiment with an innovation, their comfort increases, thus improving the chances of them adopting it (Agarwal \& Prasad, 1998 and Rogers (2003), and Al-jabri \& Sohail, 2012). It is proposed that trialability (Proposition P2-2) will positively influence AI, cloud computing and DLT adoption.

'User insecurity' describes the user's distrust of the new technology (Nugroho \& Fajar, 2017). The greater the users' insecurity, the more they feel unsafe when using the technology, which in turn influences their adoption decision. Walczuch, Lemmink and Streukens (2007) found that insecure employees in financial services firms had a negative perception of the ease of use of IT. It is proposed that user insecurity (Proposition P2-3) will negatively influence AI, cloud computing and DLT adoption.

\section{Effects of industry characteristics on innovation adoption}

'Industry characteristics' describe the extent to which a firm believes that the industry in which the firm operates is conducive to innovation adoption (Van den Berg \& Van der Lingen, 2019). Partnerships between financial regulators and fintech firms have had the potential to strengthen innovation in the sector (Saksonova \& Kuzmina-Merlino, 2017). Alt and Puschmann (2012) indicated that the evolving needs of banking customers enabled fintech firms to enter the market and offer customer-oriented financial solutions. It is proposed that industry characteristics (Proposition P3) will influence AI, cloud computing and DLT adoption.

'Competitive pressure' refers to the pressure arising from the probability of losing competitive advantage (Lin, 2014). Lin and Lin (2008) found competitive pressure to have a positive influence on the external diffusion of e-business. Verma and Chaurasia (2019) found competitive pressure to have a significant influence on the adoption of big data analytics. It is proposed that competitive pressure (Proposition P3-1) will positively influence AI, cloud computing and DLT adoption.

'Regulatory support' describes the assistance provided by regulatory bodies in promoting IT innovation by firms in a particular industry (Ling in Amini \& Bakri, 2015). Stringent compliance and data privacy laws may inhibit firms' abilities to innovate. Regulatory support was found to positively influence the adoption of cloud computing technologies in Malaysian SMEs (Amini \& Bakri, 2015). It is proposed that regulatory support (Proposition P3-2) will positively influence AI, cloud computing and DLT adoption.

'Customer demands', amongst other environmental factors, exert normative pressures in an organisation, thus influencing innovation adoption (Awa et al., 2017). Awa et al. (2017) found that the presence of normative pressures positively influenced technology adoption amongst small services enterprises in West Africa. It is proposed that customer demands (Proposition P3-3) will positively influence AI, cloud computing and DLT adoption.

\section{Effects of organisational leadership on innovation adoption}

The tactical and strategic direction of an organisation is largely influenced by the peculiar attributes of powerful actors (Awa et al., 2017). Leadership plays a significant role in motivating strategic flexibility and generating higher business benefits (Kristianto, Ajmal, Tenkorang, \& Hussain, 2012). Aziz, Md Rami, Razali and Mahadi (2020) discovered authentic leadership to play a significant role in managing technological changes within organisations in the oil and gas industry. Furthermore, Schepers, Wetzels and De Ruyter (2005) proposed that organisational leadership (Proposition P4) will influence AI, cloud computing and DLT adoption.

'Opinion leadership' refers to the extent to which a leader can frequently and informally influence other individuals' attitudes (Rogers \& Shoemaker, 1983). These leaders are characterised as having significant access to external communication, possessing high socio-economic status and exhibiting high levels of innovativeness (Rogers \& Shoemaker, 1983). It is proposed that opinion leadership (Proposition P41) will positively influence AI, cloud computing and DLT adoption.

Risk-seeking executives are more likely to pursue aggressive corporate growth strategies, and are, thus, more likely to embrace innovative initiatives, including technologies (Czaja \& Shari, (1998) and Venkatesh \& Morris (2000), in Van den Berg \& Van der Lingen, 2019). It is proposed that decision makers' risk orientation (Proposition P4-2) will positively influence AI, cloud computing and DLT adoption.

\section{Effects of organisational characteristics on innovation adoption}

'Organisational characteristics' describe the degree to which the attributes of the firm are perceived to promote or restrict innovation adoption. It is proposed that organisational characteristics (Proposition P5) will influence AI, cloud computing and DLT adoption.

Larger firms tend to be more comfortable and assured when faced with decisions to adopt innovations (Aboelmaged, 
2014). Arslan, Bagchi and Kirs (2019) indicated that larger firms were more likely to adopt innovative information communication technologies owing to their comparative resource advantage. It is proposed that increasing firm size (Proposition P5-1) will positively influence AI, cloud computing and DLT adoption.

Top management support is amongst the key contributing factors to a supportive work environment (Al-jabri \& Alabdulhadi, 2016). Adoption levels of cloud computing technologies in Malaysian SMEs were higher when supported by top management (Amini \& Bakri, 2015). It is proposed that top management support (Proposition P5-2) will positively influence AI, cloud computing and DLT adoption.

Rogers and Shoemaker (1983) highlight the positive influence that open communication structures have on innovation diffusion, as information can be disseminated across a wider group of individuals. Lee, Lee and Schuman (2005) indicated that communication factors could serve as significant predictors in the adoption of electronic banking technologies. It is proposed that effective communication mechanisms (Proposition P5-3) will positively influence AI, cloud computing and DLT adoption.

\section{Methodology}

The phenomenological research philosophy is commonly adopted in management research, owing to the dynamic nature of organisational culture (Saunders, Lewis, \& Thornhill, 2000, p. 86). Although the analysis and interpretation of qualitative data may be a complex exercise, phenomenological research enables a thorough understanding into people's meanings (Easterby-Smith, Thorpe, Jackson, \& Jasperen, 2018).

An exploratory research design was used to uncover adoption determinants and their influential constructs. A qualitative approach was used to generate textual data via semi-structured interviews and a focus group interview. The focus group interview consisted of four respondents from the banking sector, fintech fraternity, regulatory and compliance, as well as the insurance sector, respectively. It is important to note the potential threats to a qualitative study's reliability and validity including participant error and bias, as well as observer error and bias, respectively (Saunders et al., 2000, p. 86).

Triangulation using the literature review's findings, one-onone interviews and a focus group interview was used to strengthen the study's reliability. Because of the limited number of participants interviewed in this study, it follows then that external validity, also referred to as generalisability, could pose a threat to the research. The results drawn from this research could then be used as grounding theory towards generating further generalisable research on the adoption of AI, cloud computing and DLT in the SA financial sector.

The semi-structured interview enabled the generation of rich in-depth information from the respondents' perspectives (McCallum \& Viviers, 2020). It is presented in Appendix 1.
The interviews were recorded and data were transcribed as text and coded to eliminate irrelevant data.

Data were collected from purposively-selected technology experts in the SA financial sector. Selection was based on the respondents' extensive experience in the development of technology solutions and the administration of financial regulatory and compliance policies in the SA financial sector. Interviews were conducted using virtual online platforms including Google Hangouts, Microsoft Teams and Zoom. Seventeen respondents were interviewed from the following sectors: banking (five), insurance (three), fintech (five) and financial regulation and compliance (four respondents). Table 2 outlines the respondents' roles, areas of expertise and total working experience.

A thematic network analysis was used to analyse qualitative data emanating from the interviews. Thematic network diagrams are web-like structures which systematically summarise the main themes within textual data (AttrideStirling, 2001). The themes generated from the qualitative data consisted of basic themes, organising themes and global themes. Basic themes are the most lower-ordered themes evident in the text and provide little information on their own. They are categorised to form an organising theme. Organising themes are categories of basic themes which have been organised into clusters of similar ideas. And lastly, global themes are super-ordinate themes, which summarise the key metaphors in the text holistically (Attride-Stirling, 2001).

TABLE 2: Respondents' roles, fields of expertise and experience.

\begin{tabular}{|c|c|c|c|}
\hline $\begin{array}{l}\text { Respondent's } \\
\text { number }\end{array}$ & Respondent's role & Area of expertise & $\begin{array}{c}\text { Working } \\
\text { experience } \\
\text { (in years) }\end{array}$ \\
\hline [1] & Data scientist & $\mathrm{Al}$ and $\mathrm{ML}$ & 4 \\
\hline [2] & $\begin{array}{l}\text { Data and reporting } \\
\text { specialist }\end{array}$ & $\begin{array}{l}\text { Cloud computing } \\
\text { technology }\end{array}$ & 16 \\
\hline [3] & $\begin{array}{l}\text { Managing } \\
\text { director/4IR advisory } \\
\text { council member }\end{array}$ & $\begin{array}{l}\text { Financial risk, compliance } \\
\text { and governance }\end{array}$ & 17 \\
\hline [4] & Blockchain architect & DLT & 13 \\
\hline [5] & Co-founder and CEO & Conversational $\mathrm{Al} /$ Fintech & 11 \\
\hline [6] & $\begin{array}{l}\text { Lead machine learning } \\
\text { engineer }\end{array}$ & $\begin{array}{l}\text { Al, ML and cloud computing } \\
\text { technology }\end{array}$ & 6 \\
\hline [7] & Data science manager & $\begin{array}{l}\text { Al, ML and cloud computing } \\
\text { technology }\end{array}$ & 4 \\
\hline [8] & $\begin{array}{l}\text { Anti-money laundering } \\
\text { analyst }\end{array}$ & $\begin{array}{l}\text { Financial risk, compliance } \\
\text { and governance }\end{array}$ & 14 \\
\hline [9] & $\begin{array}{l}\text { Technical founder and } \\
\text { CEO }\end{array}$ & Fintech & 5 \\
\hline [10] & $\begin{array}{l}\text { Machine learning } \\
\text { specialist }\end{array}$ & $\mathrm{Al}$ and $\mathrm{ML}$ & 5 \\
\hline [11] & $\begin{array}{l}\text { Innovation and business } \\
\text { development / author }\end{array}$ & Fintech & 4 \\
\hline [12] & Statistical data scientist & $\mathrm{Al}$ and $\mathrm{ML}$ & 10 \\
\hline [13] & $\begin{array}{l}\text { IT and data risk } \\
\text { manager }\end{array}$ & $\begin{array}{l}\text { Financial risk, compliance } \\
\text { and governance }\end{array}$ & 5 \\
\hline [14] & $\begin{array}{l}\text { Head of merchant } \\
\text { analytics }\end{array}$ & Fintech & 10 \\
\hline [15] & Enterprise architect & $\begin{array}{l}\text { Cloud computing } \\
\text { technology }\end{array}$ & 21 \\
\hline [16] & Data scientist & $\mathrm{Al}$ and $\mathrm{ML}$ & 8 \\
\hline [17] & $\begin{array}{l}\text { Business development } \\
\text { manager }\end{array}$ & $\begin{array}{l}\text { Financial risk, compliance, } \\
\text { and governance }\end{array}$ & 19 \\
\hline
\end{tabular}

CEO, Chief Executive Officer; $\mathrm{Al}$, artificial intelligence; ML, machine learning; DLT, distributed ledger technologies; 4IR, fourth industrial revolution. 


\section{Ethical considerations}

This article followed all ethical standards for research without direct contact with human or animal subjects.

\section{Results and discussion Individual level determinant}

The results on individual level determinants, namely, adopter traits and technology utilisation, and their respective constructs are discussed in the following subsections.

\section{Adopter traits}

Knowledge of innovation: Awareness, exposure and a highlevel understanding of 4IR technologies were found to influence technology adoption. An acute exposure to ML and AI was found to influence short-term usage intent, whereas long-term use behaviour was significantly influenced by the need for the technologies in the lives of consumers. This was prevalent amongst respondents in the banking sector.

Exposure was influenced by individual adopters' personal experiences with the technology. For example, individuals who had been exposed to the negative aspects of emerging technologies were less likely to adopt these technologies. It was, thus, crucial to have credible sources introducing concepts of 4IR technologies to potential adopters in order to improve adoption.

Adequate knowledge of emerging technologies, particularly $\mathrm{AI}$ and DLT, had a role to play in reducing the fears arising from a lack of understanding of these technologies. Respondents in the insurance and financial regulatory sectors were concerned about potential job losses arising from the proliferation of 4IR technologies in the sector. These findings are supported by the following statements:

[4] ' [... I]f we say that blockchain is used for hiding illicit activities from government, they're most likely to stay away from it.

[3] 'The unions are acutely aware that robots are going to replace humans, and are not yet at the point of understanding what we are saying when we say unemployment might not increase.'

These findings support proposition P1-1, and suggest that knowledge of the innovation positively influences technology adoption.

Technical skill: Technical training and sufficient work experience were beneficial for the adoption of 4IR technologies amongst working professionals. However, this was not as relevant to end-users. Instead, end-users were more concerned about the value that the technologies would add to their lives than with the technical components comprising these technologies.

Sufficient technical understanding of emerging technologies by professionals enabled them to develop technologies that were beneficial to their customers or the financial institutions that employed them. For example, a thorough understanding of DLT and ML enabled investment banks to research and develop technology that would reduce interbank settlement periods from days to minutes. Retail banks were also able to leverage AI to improve profitability whilst reducing operating costs.

These findings support proposition P1-2, and suggest that technical skill positively influences technology adoption.

Personal innovativeness: Personal innovativeness was characterised by basic constructs such as the willingness to innovate, a curiosity about exploration and the ability to take risks and try out new technologies as they become available. These basic constructs had a stronger influence on individuals' (both professionals and customers) adoption intent and use behaviour than those that characterised the technical skill organising construct.

Individuals who were willing to try out ML and AI were more likely to adopt these technologies than individuals who had the technical skill but lacked the willingness. This was prevalent amongst respondents from the banking and insurance sectors. Whenever individuals had the curiosity to explore the benefits that the bank could harness from these technologies, they were able to motivate the acquisition of resources (budget allocation, hiring of skilled professionals, etc.) for technology adoption. These findings are supported by the following statement:

[1] 'I found that your sponsor doesn't have to be an AI expert, but must have the willingness to adopt data-driven principles and have the willingness to see that data is useful.'

These findings support proposition P1-3, and suggest that personal innovativeness has a strong positive influence on technology adoption. It can, thus, be inferred from the findings that adopter traits are an influential determinant of the adoption intent and use behaviour with emerging 4IR technologies in the SA financial sector.

\section{Technology usability}

Trialability: The ability of data scientists to experiment with AI prior to large-scale development reduced the risk of failure. This culture encouraged technologists to 'fail fast and recover quickly', thus contributing to innovation. Deploying ML algorithms in a phased approach increased the chances of obtaining successful outcomes. It also enabled data scientists to demonstrate the benefits of AI to the rest of the business, and garner support from executives. The following statement supports this finding:

[4] 'Introducing it through small iterations, just changing one non-core function of the bank and putting that on a decentralised network and showing value, and it gets the right kind of people at the right levels to get excited about the technology.'

Customers also preferred to test new technology before fully adopting and using it in long-term. This also minimised the potential risks associated with the technology, creating a sense of comfort for the customer. The following statement supports this finding: 
[2] 'People like to try things to see that it will work and benefit them.'

These findings support proposition P2-1, and suggest that trialability positively influences technology adoption.

Complexity: Customers were very quick to abandon the use of a new technology if they experienced it as complex. This increased firms' technology marketing efforts, and subsequently the costs associated with the technology. At the firm level, cloud computing platforms increasingly became the preferred data storage mechanism owing to the reduced maintenance costs. The complexity associated with DLT inhibited firms from trying out blockchain-related technologies. The following statement supports these findings:

[4] 'Some companies are saying that this type of technology will never work because of the sheer complexity involved.'

Delays caused by the complexity of deploying AI models rendered the models irrelevant to solving the business problems for which they were specifically designed. These models then had to be retrained with new data, which further reduced confidence in the adoption of AI. This was prevalent amongst fintech firms.

These findings support proposition P2-2, and suggest that complexity has a negative influence on technology adoption.

User insecurity: Professionals in the banking and insurance sectors were concerned that cloud computing and AI would make their current technical expertise irrelevant, potentially leading to job losses. This discomfort was exacerbated by the high unemployment levels in SA, and generated scepticism about the adoption of these technologies. Cyber security concerns also inhibited adoption, particularly in banking institutions. Professionals were also concerned about the misrepresentation of $\mathrm{AI}$ and ML and the types of problems these technologies could solve. It was feared that ongoing misrepresentation would generate a negative sentiment about the technology, and contribute to reduced adoption. The following statement supports these findings:

[6] '[...P] eople are just like so fed up of how much under-delivery that $\mathrm{AI}$ and machine learning is bringing in. Because people don't understand what it is, but they've pitched it in the wrong way.'

These findings support proposition P2-3, and suggest that user insecurity negatively influences technology adoption. It can, thus, be inferred that technology usability is an influential determinant of the adoption of emerging 4IR technologies in the SA financial sector.

\section{Firm level determinant}

The results on firm level determinants, namely, industry characteristics, organisational leadership and organisational characteristics, and their respective constructs are discussed in the following subsection.

\section{Industry characteristics}

Competitive pressures: Banks relied significantly on technology as a source of competitive advantage, and this generated interest in AI adoption in the sector. The agility of fintech firms exerted pressure on incumbent financial institutions to accelerate innovation.

Unlike AI, cloud computing technology did not generate a clear-cut competitive advantage for adopting firms. This was attributed to the costs, which often reversed the benefits of the technology. Firms were motivated by the ability to leverage cloud computing platforms to service clients more seamlessly, thus gaining a competitive edge over rivals. The following statement supports these findings:

[6] 'And if the competitors are making use of machine learning and AI, and that's caused a lot of excitement in the market, and people are leaning in that direction, then people are bound to feel the pressure, and they're going to try and adopt these things even if they aren't ready for it.'

These findings support proposition P3-1, and suggest that competitive pressure positively influences technology adoption.

Regulatory support: Financial regulators in SA were reported to have consulted widely about the adoption of $4 \mathrm{IR}$ technologies. However, the reactive nature of the regulators inhibited adoption, as innovating firms would be expected to explain their innovations to the regulators. This was attributed to a lack of understanding of the technology.

A proof-of-concept called 'Project Khokha', facilitated by the SARB, was used as one example of the consultative approach taken by regulators to promote the adoption of DLT and improve the settlements infrastructure in the banking sector. Amendments to the existing policy framework were recommended to improve the industry's adoption of emerging technologies whilst maintaining regulatory oversight on the use of these technologies.

The regulation of fintech start-ups was minimal to nonexistent. This was attributed to the nature of the data used by fintech firms, as it was deemed to be less sensitive than that used by regulated financial institutions. A lack of understanding of the risks associated with emerging innovations also contributed to the lack of regulatory oversight.

These findings support proposition P3-2, and indicate that regulatory support positively influences technology adoption.

Customer demands: Clients with a significant stake in a firm had a strong influence on the firm's technology strategy, including its adoption of emerging technologies. For fintech firms, shareholders could significantly influence senior management to incorporate AI in their innovation strategies. Investment banks also yielded to the demands of clients with a significant financial stake in the bank. However, individual retail banking clients and insurance 
policy holders had a weaker influence on the technology adopted by their service providers. These clients were increasingly using digital channels as a way to engage. The wide adoption of smart devices by individual and retail clients was a strong motivating factor for fintech start-ups as they built innovations that leveraged smart devices. Regulators were also prompted to establish working groups to respond to the rate at which regulated institutions were adopting ML, AI and DLT. The following statement supports these findings:

[4] 'The biggest thing for us as an investment bank is that we need to serve our customers the best way possible.'

These findings support proposition P3-3, and suggest that customer demands positively influence technology adoption. It can, thus, further be suggested from the findings that industry characteristics (proposition P3) are an influential determinant towards the adoption use behaviour of $\mathrm{AI}$, cloud computing and DLT in the SA financial sector.

\section{Organisational leadership}

Opinion leadership: Opinion leaders played a significant role in persuading the organisation to accept 4IR technologies. In the banking environment, these leaders had great foresight into market trends, and were able to influence senior management to support the development of AI, DLT and ML platforms. The following statement supports these findings:

[1] 'When he speaks, everyone wants to listen. I think he was one of the early adopters.'

Leaders who inspired employees to take part-ownership of the innovation strategy were more effective in influencing banking institutions to adopt 4IR technologies. This created a community of leaders in the bank, instead of a single focal point of leadership.

In fintech firms, leaders were also founders and or shareholders in the firms, and had a significant influence over the firms' technology strategies. This generated a lack of diversity in the leadership opinion governing the firm, and negatively impacted the chances of successfully adopting innovations. Diversity in the leadership structures was necessary to interrogate the business need and clearly articulate the capabilities of AI for the adopting firm.

These findings provide support for proposition P4-1, and suggest that opinion leadership positively influences technology adoption. In addition to opinion leadership, leadership diversity was also found to influence technology adoption positively.

Decision-maker risk orientation: Emerging 4IR technologies represented uncharted territories in which the potential benefits of technologies such as AI were not yet fully understood. Therefore, it was crucial for leaders in a firm to acquire resources in the awareness that the expected benefits might not be realised. The following statement supports these findings:
[4] 'Leaders will understand that this is a nascent technology, and you must be willing to take some level of risk.'

These findings suggest that the decision-makers' risk orientation positively influences technology adoption, in line with proposition $\mathrm{P} 4-2$. It can be inferred from these findings that organisational leadership is an influential determinant of the adoption of emerging 4IR technologies in the SA financial sector.

\section{Organisational characteristics}

Firm size: Fintech start-up firms were more agile than larger incumbent financial institutions, and had insignificant legacy constraints (people, processes and technologies) to overcome when adopting innovations. In the context of cloud computing technologies, fintech firms were swift to replace on-site data centres with cloud infrastructure. Fintech firms implementing conversational AI technology were able to react swiftly to their customers' demands, constantly improving their product offerings to suit their market.

Larger incumbent financial institutions, particularly regulated banks and insurance firms, were more risk-averse, and had significant protocols in place that hindered the proliferation of emerging 4IR technologies in these organisations. However, where technology adoption was successful, these institutions were able to reach larger adoption scales owing to the significant number of resources at their disposal. The following statement supports these findings:

[5] 'When smaller companies take on the new technology, they do it faster and go into market with it faster, but the bigger companies are slower in adopting, but they can implement them easier because they have the financial capacity.'

These findings, therefore, do not support proposition P5-1, and indicate that neither increasing nor decreasing the firm's size influences technology adoption.

Top management support: Senior executives in the banking sector have a key role to play in articulating the necessity of AI technology adoption by a bank. These leaders could incentivise ideation processes in the organisation, motivating employees to solve business problems using ML. Senior managers were also tasked with outlining the bank's strategic direction, and so were not expected to take a conservative approach to innovation. Having innovation champions at the senior executive level was also essential to acquiring financial resources and communicating the need for innovation amongst other senior business executives. The following statement supports these findings:

[2] 'I think it is more about having a vision and strategy from a $\mathrm{CIO}$ level of management to accept that technology needs to be part of the overall vision and roadmap.'

Departments in the banks whose CEOs were cognisant of cloud computing technology encountered fewer challenges during the deployment of this technology. Amongst insurers, CIOs who managed to articulate an innovation strategy 
clearly, to facilitate transparency and to celebrate successes were more effective in encouraging cloud computing technology adoption in their departments.

These findings support the proposition P5-2, and suggest that top management support positively influences technology adoption.

Communication mechanisms: Flatter organisational structures were more effective in disseminating information across the organisation, and thus were more conducive to innovation. Effective communication mechanisms enabled senior bank managers to diffuse strategy across the organisation and enable employees to communicate their innovative technological ideas to senior management. The following statements support these findings:

[2] ' [... C]ommunication is very important, and it should be a two-way thing so that people can give feedback and suggestions and present the skills that they have.'

[7] 'To show that the flat system works, me as the manager of the data science division, I was able to communicate with the CEOs of the retail division and engage my teams' work to the ... group CEO.'

These findings support proposition P5-3, and suggest that effective communication structures positively influence technology adoption. It can, thus, further be suggested from the findings that effective communication structure (proposition P5) is an influential determinant towards the adoption use behaviour of AI, cloud computing and DLT in the SA financial sector.

\section{Conclusion}

This article reveals the determinants influencing 4IR technology adoption in SA financial services firms. This was obtained by means of a proposed model using existing determinants from the DOI, TOE and TRI adoption models. A semi-structured interview tool was used to assess qualitatively the validity of the model in a series of one-onone interviews, followed by a focus group discussion.

The results indicated that at the individual level, the model constructs of knowledge of innovation, technical skill, personal innovativeness and trialability promoted technology adoption, whilst complexity and user insecurity inhibited adoption. At the firm level, competitive pressure, regulatory support, customer demands, decision-maker risk orientation, opinion leadership, effective communication mechanisms and top management supported adoption. Firm size was found to have no influence on technology adoption. The results validated the model in predicting the adoption of emerging 4IR technologies in the SA financial sector at both individual and firm levels.

This study contributes to the limited research on this topic by presenting a new model to assist technology leaders in better understanding the determinants of 4IR technology adoption. Although leaders are encouraged to take calculated risks in adopting technology, articulating the business need for these technologies is also emphasised.

This research was limited to the SA financial sector, and focused on the banking, insurance, fintech and financial regulation and compliance sectors. It also examined the adoption of AI, ML, DLT and cloud computing technologies.

Future studies could focus on a specific emerging 4IR capability to generate in-depth knowledge on the topic. Quantitative studies would improve the ability to generalise findings. The findings also indicated that the new model could be strengthened by incorporating a new construct, leadership diversity, which had not been proposed in the literature.

\section{Acknowledgements}

The authors are thankful to the Graduate School of Technology Management, University of Pretoria, for permission to publish the results.

\section{Competing interests}

The authors have declared that no competing interest exists.

\section{Authors' contributions}

Both authors contributed to the development and writing of the article. N.T. Matsepe conducted the research as part of his Master's dissertation under the supervision of Prof E. van der Lingen.

\section{Funding information}

This research received no specific grant from any funding agency in the public, commercial or not-for-profit sectors.

\section{Data availability}

Raw data were generated at the University of Pretoria. Derived data supporting the findings of this study are available from the corresponding author upon reasonable request.

\section{Disclaimer}

The views and opinions expressed in this article are those of the authors and do not necessarily reflect the official policy or position of any affiliated agency of the authors.

\section{References}

Aboelmaged, M.G. (2014). Predicting e-readiness at firm-level: An analysis of technological, organizational and environmental (TOE) effects on e-maintenance readiness in manufacturing firms. International Journal of Information Management, 34(5), 639-651. https://doi.org/10.1016/j. ijinfomgt.2014.05.002

Agarwal, R., \& Prasad, J. (1998). A conceptual and operational definition of personal innovativeness in the domain of information technology. Information Systems Research, 9(2), 204-215. https://doi.org/10.1287/isre.9.2.204

Albrecht, C., Morales, V., Baldwin, J.K., \& Scott, S.D. (2017). Ezubao: A Chinese Ponzi scheme with a twist. Journal of Financial Crime, 24(2), 56-259. https://doi. org/10.1108/JFC-04-2016-0026 
Al-Jabri, I.M., \& Alabdulhadi, M.H. (2016). Factors affecting cloud computing adoption: Perspectives of IT professionals. International Journal of Business Information Systems, 23(4), 389-405. https://doi.org/10.1504/IJBIS.2016.10000364

Al-Jabri, I.M., \& Sohail, M.S. (2012). Mobile banking adoption: Application of diffusion of innovation theory. Journal of Electronic Commerce Research, 13(4), 379-391.

Alt, R., Beck, R., \& Smits, M.T. (2018). Fintech and the transformation of the financial industry. Electronic Markets, 28(3), 235-243. https://doi.org/10.1007/s12525018-0310-9

Alt, R., \& Puschmann, T. (2012). The rise of customer-oriented banking - Electronic markets are paving the way for change in the financial industry. Electronic Markets, 4(22), 203-215. https://doi.org/10.1007/s12525-012-0106-2

Amini, M., \& Bakri, A. (2015). Cloud computing adoption by SMEs in the Malaysia: A multi-perspective framework based on the DOI theory and TOE framework. Journa of Information Technology \& Information Systems Research, 9(2), 121-135.

Arner, D., Barberis, J., \& Buckley, R. (2016). The evolution of fintech: A new post-crisis paradigm? Georgetown Journal of International Law, 47, 1271-1319. https://doi. org/10.2139/ssrn.2676553

Arslan, F., Bagchi, K.K., \& Kirs, P. (2019). Factors implicated with firm-level ICT use in developing economies. Journal of Global Information Technology Management, 22(3), 179-207. https://doi.org/10.1080/1097198X.2019.1642022

Attride-Stirling, J. (2001). Thematic networks: An analytic tool for qualitative research. Qualitative Research, 1(3), 385-405. https://doi.org/10.1177/ research. Qualitative
146879410100100307

Au, Y.A., \& Kauffman, R.J. (2008). The economics of mobile payments: Understanding stakeholder issues for an emerging financial technology application. Electronic Commerce Research and Applications, 7(2), 141-164. https://doi.org/10.1016/j. elerap.2006.12.004

Awa, H.O., Ojiabo, O.U., \& Orokor, L.E. (2017). Integrated technology-OrganisationEnvironment (T-O-E) taxonomies for technology adoption. Journal of Enterprise Information Management, 30(6), 893-921. https://doi.org/10.1108/JEIM-032016-0079

Aziz, F., Md Rami, A., Razali, F., \& Mahadi, N. (2020). The influence of leadership style towards technology acceptance in organization. International Journal of Advanced Science and Technology, 29(7), 218-225.

Barreto, L., Amaral, A., \& Pereira, T. (2017). Industry 4.0 implications in logistics: An overview. Procedia Manufacturing, 13, 1245-1252. https://doi.org/10.1016/j. promfg.2017.09.045

Centre of Excellence in Financial Services. (2017). The impact of the 4th industria revolution on the South African financial services market. Johannesburg: Centre of Excellence in Financial Services. Retrieved from www.Coefs.org.za.

Cheung, W., Chang, M.K., \& Lai, V.S. (2000). Prediction of internet and world wide web usage at work: A test of an extended Triandis model. Decision Support Systems, 30(1), 83-100. https://doi.org/10.1016/\$0167-9236(00)00125-1

Coetzee, J. (2018). Strategic implications of fintech on South African retail banks. South African Journal of Economic and Management Sciences, 21(1), 1-11. South African Journal of Economic and
https://doi.org/10.4102/sajems.v21i1.2455

Czaja, S., \& Sharit, J. (1998). Age difference in attitudes towards computer. Journal of Gerontology Series B: Psychological Sciences, 53(5), 329-341. https://doi. org/10.1093/geronb/53B.5.P329

Easterby-Smith, M., Thorpe, R., Jackson, P.R., \& Jasperen, L.J. (2018). Management \& business research (6th ed.). London: Sage.

Gerlach, C.A., Simmons, R., \& Lam, S. (2016). U.S. regulation of FinTech - Recent developments and challenges. Journal of Financial Transformation, 44, 87-96.

Haddud, A., Desouza, A., Khare, A., \& Lee, H. (2017). Examining potential benefits and challenges associated with the Internet of things integration in supply chains. Journal of Manufacturing Technology Management, 28(8), 1055-1085. https:// doi.org/10.1108/JMTM-05-2017-0094

Hassani, H., Unger, S., \& Beneki, C. (2020). Big data and actuarial science. Big Data and Cognitive Computing, 4(4), 40. https://doi.org/10.3390/bdcc4040040

Jaafar, M., Ramayah, T., Abdul-Aziz, A., \& Saad, B. (2007). Technology readiness among managers of Malaysian construction firms. Engineering, Construction and Architectural Management, 14(2), 180-191. https://doi.org/10.1108/096999 80710731290

Kristianto, Y., Ajmal, M., Tenkorang, R.A., \& Hussain, M. (2012). A study of technology adoption in manufacturing firms. Journal of Manufacturing Technology Management, 23(2), 198-211. https://doi.org/10.1108/17410381211202197

Kunwar, M. (2019). Artificial intelligence in finance: Understanding how automation and machine learning is transforming the financial industry. Dissertation. Centria University of Applied Sciences.

Lai, P.C. (2017). The literature review of technology adoption models and theories for the novelty technology. Journal of Information Systems and Technology Management, 14(1), 21-38. https://doi.org/10.4301/S1807 17752017000100002

Lee, E.-J., Lee, J., \& Schumann, D. (2005). The influence of communication source and mode on consumer adoption of technological innovations. Journal of Consumer Affairs, 36, 1-27. https://doi.org/10.1111/j.1745-6606.2002.tb00418.x
Lin, H. (2014). Understanding the determinants of electronic supply chain management system adoption: Using the Technology-Organization-Environment framework. Technological Forecasting \& Social Change, 86, 80-92. https://doi. framework. Technological Forecasting
org/10.1016/j.techfore.2013.09.001

Lin, H., \& Lin, S. (2008). Determinants of e-business diffusion: A test of the technology diffusion perspective. Technovation, 28, 135-145. https://doi.org/10.1016/j. technovation.2007.10.003

Mallat, N. (2007). Exploring consumer adoption of mobile payments - A qualitative study. Journal of Strategic Information Systems, 16(4), 413-432. https://doi. org/10.1016/j.jsis.2007.08.001

McCallum, S., \& Viviers, S. (2020). Exploring key barriers and opportunities in impact investing in an emerging market setting. South African Journal of Business Management, 51(1), 1-11. https://doi.org/10.4102/sajbm.v51i1.1601

Md Husin, M., Haron, R., \& Aziz, S. (2020). Adoption of financial technology in Islamic crowd-funding: Predicting small and medium-sized enterprises' intention to use the investment account platform. In N. Naifar (Ed.), Impact of financial technology (FinTech) on Islamic finance and financial stability (pp. 12-35). Hershey, PA: IGI Global.

Miranda, M.Q., Farias, J.S., Schwartz, C.D.A., Pascualote, J., \& De Almeida, L. (2016). Technology adoption in diffusion of innovations perspective: Introduction of an ERP system in a non-profit organization. RAl Revista de Administração e Inovação, 13(1), 48-57. https://doi.org/10.1016/j.rai.2016.02.002

Nugroho, M.A., \& Fajar, M.A. (2017). Effects of technology readiness towards acceptance of mandatory web-based attendance system. Procedia Computer Science, 124, 319-328. https://doi.org/10.1016/j.procs.2017.12.161

Nugroho, M.A., Susilo, A.Z., Fajar, M.A., \& Rahmawati, D. (2018). Exploratory study of SMEs technology adoption readiness factors. Procedia Computer Science, 124 329-336. https://doi.org/10.1016/j.procs.2017.12.162

OECD. (2018). Financial markets, insurance and private pensions: Digitalisation and finance.

Ondrus, J., \& Pigneur, Y. (2006). Towards a holistic analysis of mobile payments: A multiple perspectives approach. Electronic Commerce Research and Applications, 5(3), 246-257. https://doi.org/10.1016/j.elerap.2005.09.003

Parasuraman, A., \& Colby, C.L. (2001). Techno-ready marketing: How and why your customers adopt technology. New York, NY: The Free Press.

Propson, D., \& Galaski, R. (2020). Forging new pathways: The next evolution of innovation in financial services [online]. Retrieved from https://www.weforum.org/reports/ forging-new-pathways-the-next-evolution-of-innovation-in-financial-services

Puschmann, T. (2017). Fintech. Business \& Information Systems Engineering, 59(1), 69-76. https://doi.org/10.1007/s12599-017-0464-6

Rogers, E. (2003). Diffusion of innovations. New York, NY: Free Press.

Rogers, E.M., \& Shoemaker, F. (1983). Diffusion of innovation: A cross-cultura approach (3rd ed.). New York, NY: The Free Press.

Saksonova, S., \& Kuzmina-Merlino, I. (2017). The possibilities and problems of implementation. European Studies Journal, 20(3A), 961-973. https://doi. org/10.35808/ersj/757

Saunders, M.N.K., Lewis, P., \& Thornhill, A. (2000). Research methods for business students (2nd ed.). London: Pearson Education Limited.

Schepers, J., Wetzels., M., \& De Ruyter, K. (2005). Leadership styles in technology acceptance: Do followers practice what leaders preach? Managing Service Quality, 15(6), 496-508. https://doi.org/10.1108/09604520510633998

South African Reserve Bank (SARB). (2017). Financial stability review (1st ed.). Pretoria: Financial Stability Unit, SARB.

Taherdoost, H. (2018). A review of technology acceptance and adoption models and theories. Procedia Manufacturing, 22, 960-967. https://doi.org/10.1016/j promfg.2018.03.137

Tselentis, D.I., Yannis, G., \& Vlahogianni, E.I. (2016). Innovative insurance schemes: Pay as/how you drive. Transportation Research Procedia, 14, 362-371. https:// doi.org/10.1016/j.trpro.2016.05.088

Van den Berg, J., \& Van der Lingen, E. (2019). An empirical study of the factors affecting the adoption of mobile enterprise applications. South African Journal of Industrial Engineering, 30(1), 124-146. https://doi.org/10.7166/30-1-1992

Venkatesh, V., \& Morris, M. (2000). Why don't men ever stop to ask for directions? Gender, social influence and their role in technology acceptance and usage Gender, social influence and their role in technology acceptance and
behavior. MIS Quarterly, 24(1), 115-139. https://doi.org/10.2307/3250981

Verma, S., \& Chaurasia, S. (2019). Understanding the determinants of big data analytics adoption. Information Resources Management Journal, 32(3), 1-26. https://doi.org/10.4018/IRMJ.2019070101

Walczuch, R., Lemmink, J., \& Streukens, S. (2007). The effect of service employees' technology readiness on technology acceptance. Information \& Management, 44, 206-215. https://doi.org/10.1016/j.im.2006.12.005

Wang, J. (2018). Reasons and theoretical explanations for the rapid development of Internet Finance in China. The secret worry and countermeasures. In: H.Q. Zhou (Ed.), International symposium on social science and management innovation (SSMI 2018) (pp. 415-421), 15-16 December, 2018. Xi'an City: Atlantis Press.

Zalan, T., \& Toufaily, E. (2017). The promise of fintech in emerging markets: Not as disruptive. Contemporary Economics, 11(4), 415-430. 


\section{Appendix 1}

TABLE 1 A1: The research instrument.

\begin{tabular}{|c|c|c|c|}
\hline Construct & Code & Description & Reference \\
\hline \multirow[t]{3}{*}{ Selection criteria } & N/A & What is your current role in your line of work? & Subject matter expertise \\
\hline & N/A & $\begin{array}{l}\text { In which sector within the South African financial services industry do you operate? Insurance, } \\
\text { banking, financial regulation or fintech sector? }\end{array}$ & Sector classification \\
\hline & N/A & $\begin{array}{l}\text { To which 4IR technologies have you been exposed to, and to what extent has your exposure } \\
\text { been? }\end{array}$ & 4IR technology classification \\
\hline \multirow[t]{4}{*}{ Adopter traits } & AT1 & $\begin{array}{l}\text { How does being exposed to } 4 I R \text { technologies such as Al, big data, cloud computing and } \\
\text { blockchain influence the intent to adopt these technologies? }\end{array}$ & Knowledge of innovation \\
\hline & AT2 & $\begin{array}{l}\text { In what manner does the awareness of these technologies influence an individual's decision to } \\
\text { use these technologies on a prolonged basis? }\end{array}$ & Knowledge of innovation \\
\hline & AT3 & $\begin{array}{l}\text { How does an individual's technical aptitude impact on their intent to adopt and use emerging } \\
\text { 4IR technologies to carry out daily tasks? }\end{array}$ & Technical skill \\
\hline & AT4 & $\begin{array}{l}\text { How does an individual's innate affinity with exploring new technology impact his or her intent } \\
\text { to adopt and use 4IR technologies? }\end{array}$ & Personal innovativeness \\
\hline \multirow[t]{3}{*}{ Technology usability } & TU1 & $\begin{array}{l}\text { To what extent are users able to experiment with } 4 I R \text { technologies before fully adopting and } \\
\text { using the technologies? How does the ability to experiment influence their intention to adopt } \\
\text { and use the technologies? }\end{array}$ & Trialability \\
\hline & TU2 & $\begin{array}{l}\text { To what extent are 4IR technologies relatively easy to understand and use? How does the } \\
\text { complexity of the technology influence users' adoption intent and usage? }\end{array}$ & Complexity \\
\hline & TU3 & $\begin{array}{l}\text { Is there any factor concerning } 4 I R \text { technologies that makes you feel unsafe when using the } \\
\text { technologies? If there is, how does it affect your intent to adopt and use the technologies? }\end{array}$ & User insecurity \\
\hline \multirow[t]{4}{*}{$\begin{array}{l}\text { Industry } \\
\text { characteristics }\end{array}$} & IC1 & $\begin{array}{l}\text { How does the need to gain competitive advantage over competitors influence a firm's decision } \\
\text { to adopt and use } 4 \text { IR technologies? }\end{array}$ & Competitive pressure \\
\hline & IC2 & $\begin{array}{l}\text { What role do financial regulators play in the industry-wide adoption of } 4 I \mathrm{R} \text { technologies in } \\
\text { South Africa? }\end{array}$ & Regulatory support \\
\hline & IC2 & $\begin{array}{l}\text { How do financial regulators promote or inhibit the adoption and use of 4IR technologies } \\
\text { within South African financial services organisations? }\end{array}$ & Regulatory support \\
\hline & IC3 & $\begin{array}{l}\text { How have customer demands changed over time, and has this had any influence on the } \\
\text { organisation's decision to adopt and use 4IR technologies? }\end{array}$ & Customer demands \\
\hline \multirow[t]{3}{*}{$\begin{array}{l}\text { Organisational } \\
\text { leadership }\end{array}$} & OL1 & $\begin{array}{l}\text { How do opinion leaders influence members of the firm to adopt and use 4IR technologies in } \\
\text { this sector? }\end{array}$ & Opinion leadership \\
\hline & OL1 & $\begin{array}{l}\text { Are there any other leadership styles that may be influential in } 4 I R \text { technology adoption and } \\
\text { usage in the firm? How do these styles promote or inhibit } 4 I R \text { technology adoption? }\end{array}$ & Opinion leadership \\
\hline & $\mathrm{OL} 2$ & $\begin{array}{l}\text { How do risk-seeking leaders and or managers influence the firm's intention to adopt and } \\
\text { use } 4 \mathrm{IR} \text { technologies in this sector? }\end{array}$ & Risk orientation \\
\hline \multirow[t]{4}{*}{$\begin{array}{l}\text { Organisational } \\
\text { characteristics }\end{array}$} & OC1 & $\begin{array}{l}\text { In your experience, are larger organisations more or less inclined to adopt and use } 4 \mathrm{IR} \\
\text { technologies? Why is this the case? }\end{array}$ & Firm size \\
\hline & OC2 & $\begin{array}{l}\text { What role do senior executives in the organisation play in promoting or inhibiting the } \\
\text { adoption of } 4 \text { IR technologies? }\end{array}$ & Top management support \\
\hline & OC3 & Does your organisation have effective communication channels and structures in place? & Communication mechanisms \\
\hline & OC3 & $\begin{array}{l}\text { What impact do effective communication mechanisms have on } 4 I R \text { technology adoption and } \\
\text { usage? }\end{array}$ & Communication mechanisms \\
\hline
\end{tabular}

AT, adopter traits; OC, organisational characteristics; IC, industry characteristics; TU, technology usability; OL, organisational leadership; 4IR, fourth industrial revolution; AI, artificial intelligence. 